\title{
Role of adipose tissue-derived stem cells in the progression of renal disease
}

\author{
Papel das células-tronco derivadas do tecido adiposo na progressão da doença renal \\ Cassiano Donizetti-Oliveira ${ }^{1^{*}}$, Patricia Semedo ${ }^{1^{*}}$, Marina Burgos-Silva ${ }^{1}$, Marco Antonio Cenedeze ${ }^{1}$, \\ Denise Maria Avancini Costa Malheiros ${ }^{2}$, Marlene Antônia dos Reis ${ }^{3}$, Alvaro Pacheco-Silva ${ }^{1}$, \\ Niels Olsen Saraiva Câmara ${ }^{4}$
}

\begin{abstract}
Objective: To analyze the role of adipose tissue-derived stem cells in reducing the progression of renal fibrosis. Methods: adipose tissue-derived stem cells were isolated from C57BI/6 mice and characterized by cytometry and differentiation. Renal fibrosis was established after unilateral clamping of the renal pedicle for 1 hour. Four hours after reperfusion, $2.10^{5}$ adipose tissue-derived stem cells were administered intraperitoneally and the animals were followed for 24 hours during 6 weeks. In another experimental group, $2.10^{5}$ adipose tissue-derived stem cells were administered only after 6 weeks of reperfusion, and they were euthanized and studied 4 weeks later. Twenty-four hours after reperfusion, the animals treated with adipose tissue-derived stem cells displayed reduced renal and tubular dysfunction and an increase of the regenerative process. Renal expression of IL-6 and TNF mRNA were decreased in the animals treated with adipose tissue-derived stem cells, while the levels of IL-4, IL-10, and HO-1 were increased, despite the fact that adipose tissue-derived stem cells were not observed in the kidneys via SRY analysis. Results: In 6 weeks, the kidneys of non-treated animals decreased in size, and the kidneys of the animals treated with adipose tissue-derived stem cells remained at normal size and display less deposition of type 1 collagen and FSP-1. The renal protection observed in animals treated with adipose tissue-derived stem cells was followed by a drop in serum levels of TNF- $\alpha$, KC, RANTES, and IL1a. Treatment with adipose tissue-derived stem cells after 6 weeks, when the animals already displayed established fibrosis, demonstrated an improvement in functional parameters and less fibrosis analyzed
\end{abstract}

by Picrosirius stain, as well as a reduction of the expression of type 1 collagen and vimentin mRNA. Conclusion: Treatment with adipose tissue-derived stem cells may deter the progression of renal fibrosis by modulation of the early inflammatory response, likely via reduction of the epithelial-mesenchymal transition.

Keywords: Mesenchymal stem cells; Renal insufficiency, acute; Reperfusion injury; Fibrosis; Inflammation

\section{RESUMO}

Objetivo: Analisar o papel das células-tronco derivadas do tecido adiposo na redução da progressão da fibrose renal. Métodos: célulastronco derivadas do tecido adiposo foram isoladas de camundongos C57BI/6 e caracterizadas por citometria e diferenciação. Fibrose renal foi instaurada após clampeamento unilateral do pedículo renal por 1 hora. Após 4 horas de reperfusão, $2.10^{5}$ células-tronco derivadas do tecido adiposo foram administradas por via intraperitoneal, e os animais foram acompanhados por 24 horas e 6 semanas. Em outro grupo de experimentos, $2.10^{5}$ células-tronco derivadas do tecido adiposo foram administradas somente após 6 semanas de reperfusão, e os animais foram sacrificados e estudados 4 semanas mais tarde. Após 24 horas da reperfusão, animais tratados com células-tronco derivadas do tecido adiposo apresentaram reduzida disfunção renal e tubular, além de aumento do processo regenerativo. Expressão renal de RNAm de IL-6 e TNF foi diminuída nos animais tratados com células-tronco derivadas do tecido adiposo, enquanto

\footnotetext{
Study carried out at Laboratório de Imunologia Clínica e Experimental, na Disciplina de Nefrologia - Departamento de Medicina da Universidade Federal de São Paulo - UNIFESP - São Paulo (SP), Brazil.

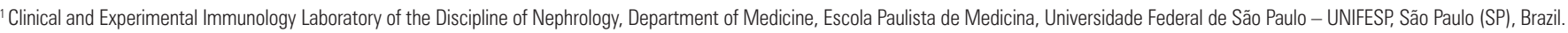
${ }^{2}$ Department of Pathology of Faculty of Medicine, Universidade de São Paulo - USP, São Paulo (SP), Brazil.

${ }^{3}$ Discipline of Pathology of Faculty of Medicine, Universidade Federal do Triângulo Mineiro - UFTM, Uberaba (MG), Brazil.

${ }^{4}$ Clinical and Experimental Immunology Laboratory of the Discipline of Nephrology, Department of Medicine, Escola Paulista de Medicina, Universidade Federal de São Paulo - UNIFESP, São Paulo (SP), Brazil. Transplant Immunology Laboratory of the Department of Immunology, Faculty of Medicine, Universidade de São Paulo - USP, São Paulo (SP), Brazil.

Corresponding author: Cassiano Donizetti de Oliveira - Rua Borges Lagoa, 678 - Vila Clementino - CEP 04038-001 - São Paulo (SP), Brazil - Tel.: $119862-3810$ - e-mail: cdo.oliveira@gmail.com

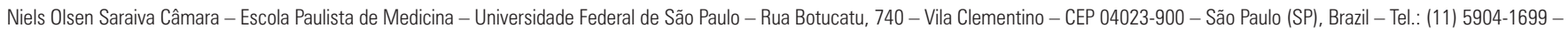
Fax: (11) 5904-1894; e-mail: niels@nefro.epm.br

This work was supported by the Fundação Brasileira; São Paulo Research Foundation (FAPESP), protocols n. 09/13251-6 and 07/07139-3; National Council for Research and Development (CNPq), protocol n. 473844/2009-5; Departamento de Ciência e Tecnologia (DECIT)/Ministério da Saúde e The National Institute of Science and Technology on Complex Fluids (INCT-FCx).

* Both authors contributed equally to the study.

The authors declare there is no conflict of interest.

Received: Jul 31, 2010 - Accepted: Dec 20, 2010
} 
IL-4, IL-10 e H0-1 foram aumentadas, apesar de células-tronco derivadas do tecido adiposo não serem observadas nos rins por meio da análise SRY. Resultados: Em 6 semanas, os rins dos animais não tratados diminuíram; no entanto, os rins dos animais tratados com células-tronco derivadas do tecido adiposo permaneceram com o tamanho normal e apresentaram menor deposição de colágeno tipo 1 e FSP-1. Proteção renal observada em animais tratados com células-tronco derivadas do tecido adiposo foi seguida por redução nos níveis séricos de TNF- $\alpha, \mathrm{KC}$, RANTES e IL-1a. 0 tratamento com células-tronco derivadas do tecido adiposo após 6 semanas, quando os animais já apresentavam fibrose instalada, demonstrou melhora em parâmetros funcionais e menos fibrose, analisada pela coloração de Picrosirius, e redução da expressão de RNAm de colágeno tipo I e vimentina. Conclusão: A terapia com células-tronco derivadas do tecido adiposo pode deter a progressão da fibrose renal, pela modulação da resposta inflamatória precoce, provavelmente por meio da redução da transição epitelial-mesenquimal.

Descritores: Células-tronco mesenquimais; Insuficiência renal aguda; Traumatismo por reperfusão; Fibrose; Inflamação

\section{INTRODUCTION}

Despite all efforts in treating acute renal failure (ARF), this syndrome is still associated with high rates of mortality and morbidity. Additionally, it displays a high incidence and may affect about $7 \%$ of all hospitalized patients, with a mortality rate close to $50 \%$ in patients in Intensive Care Units (ICUs) ${ }^{(1)}$. Among the long-term (1 to 10 years) ARF survivors, approximately $12.5 \%$ are dialysis-dependent and 19 to $31 \%$ develop chronic renal disease (CRD). This scenario may be due to incomplete reparation and persistent tubulointerstitial inflammation, leading to an increase in proliferation of fibroblasts and activation of myofibroblasts, resulting in excessive deposition of extracellular matrix ${ }^{(2)}$. The epithelial-mesenchymal transition (EMT) has been suggested as the key factor for the development of fibrosis in the progression from ARF to CRD ${ }^{(3-5)}$.

EMT maybe seen as an adaptive response of epithelial cells after chronic stress or lesion. Hypoxia, oxidative stress, and inflammation may produce and release various chemokines and cytokines that attract and direct the influx of inflammatory cells to the tubulointerstitial space. This cellular infiltrate is activated and produces a mix of soluble factors, including proinflammatory agents, profibrotic cytokines, and metallopeptidase-9 matrix (MMP-9) ${ }^{(6)}$, creating a hostile microenvironment for epithelial and endothelial cells. During the early phase of the inflammatory process in renal fibrosis, cytokines produced by the cell infiltrate such as IL-1, TNF- $\alpha$, and IFN $\gamma$, potentiate tubular EMT triggered by TGF- $\beta$, inducing the expression of the TGF- $\beta$ receptor ${ }^{(7)}$. TGF- $\beta$ is the primary profibrotic factor, since it promotes the proliferation of fibroblasts, synthesis of the extracellular matrix, and inhibition of collagenase in multiple organs, events that are characteristic of $\mathrm{EMT}^{(8,9)}$. Activation of NF-kB-dependent TNF- $\alpha$ also stabilizes the Snail transcription factor (a potent EMT inducer) blocking its ubiquitination and providing another molecular link between inflammation and $\mathrm{EMT}^{(10,11)}$. The importance of renal inflammation in initiating and promoting EMT is also manifested by many observations that renal fibrosis is always preceded by and intimately associated with chronic interstitial inflammation ${ }^{(12-14)}$.

Adipose tissue-derived stem cells (ADSCs) are adult mesenchymal stem cells ${ }^{(15)}$ that are easily isolated and, when influenced by the extracellular environment, have the capacity, in vitro, to differentiate into other cell types, such adipocytes, myocytes, osteoblasts and neurons. They are known to secrete various growth factors, and therefore, to possess a cytoprotective effect in different lesion models ${ }^{(16)}$. Gimble et al. demonstrated that when present in damaged tissues, ADSCs can secrete cytokines and growth factors that stimulate the recovery and cleansing of toxic substances released at the site of injury, promoting recovery of the surviving cells ${ }^{(17)}$. Various studies demonstrated that ADSCs also have the capacity to regulate responses of the immune system ${ }^{(18,19)}$. They can suppress activation of T-cells by inhibiting expression of cyclin $\mathrm{D} 2^{(20)}$, by inducing regulator T-cells ${ }^{(21)}$, or by interfering with dentritic cells ${ }^{(21,22)}$. Additionally, ADSCs may act by means of an anti-apoptotic effect on targetcells, increasing recovery of renal function.

Recently, therapies with stem cells have proved to be a new strategy to reduce the progression of CRD. Semedo et al. demonstrated that the administration of mesenchymal stem cells (MSCs) improved histological and functional parameters, besides reducing fibrosis in a model of serious renal ablation. The renal protection resulting from the administration of MSCs also attenuated the chronic hypoxia, oxidative stress, and inflammatory cytokines that lead to EMT and are present during $\mathrm{CRD}^{(23,24)}$. Several other studies described the beneficial effects of ADSCs administration. Treatment with ADSCs leads to better vascularization ${ }^{(25)}$, cranial bone regeneration, cardiac wall regeneration, infarcted myocardium function repair, and functional improvement after a cerebrovascular accident. In this study, we proposed that ADSCs may interrupt the progression of renal fibrosis in an animal model of CRD by modulating inflammatory events.

\section{METHODS}

\section{Isolation of ADSCs}

Adipose tissue from the inguinal region of the mouse was isolated from male $\mathrm{C} 5 \mathrm{Bl} / 6$ mice and digested with $0.075 \%$ collagenase IA (Sigma Aldrich, St Louis, MO, 
USA) at $37^{\circ} \mathrm{C}$ for 30 minutes. The cell suspension was filtered through a $70 \mu \mathrm{m}$ filter (BD Biosciences, San Jose, CA, USA) in order to remove tissue debris. The collagenase was then inactivated with fetal bovine serum (FBS) and the cell suspension was washed with a phosphate buffer (PBS) and centrifuged twice, for 5 minutes, at $260 \mathrm{xg}$ each time. The pellet formed was suspended in $0.84 \% \mathrm{NH} 4 \mathrm{Cl}$ to remove red blood cells. The cells were then washed and centrifuged twice with PBS and cultivated in plastic jars (TPP, Trasadingen, Switzerland) in low-glucose Dulbecco's modified Eagle medium (DMEM, Gibco, Invitrogen Corporation, Carlsbad, CA, USA) supplemented with $10 \%$ fetal bovine serum (Emcare, Campinas, SP, Brazil). The cells were cultured for 4 weeks.

\section{ADSCs immunophenotyping}

The suspension of ADSCs $(1 \times 105$ cells $)$ was incubated for 40 minutes in saturated concentrations of antibodies CD34-FITC, CD105-FITC, CD73-CD45-PE, and PerCP, and controls (all antibodies were acquired from BD PharMingen Biosciences, San Diego, CA, USA). After three washings, the cells were centrifuged at $200 \mathrm{xg}$ during 5 minutes and the resulting pellet was resuspended in a cold phosphate buffer (PBS). Cellular fluorescence was assessed with the use of a flow cytometer (FACSCanto, Becton Dickinson, Franklin Lakes, NJ, USA).

\section{ADSCs differentiation}

The ADSCs were differentiated into adipocytes by treatment with low glucose DMEM, supplemented with $10 \%$ FBS and dexamethasone $\left(\begin{array}{ll}1 & \mu \mathrm{M}\end{array}\right)$, isobutylmethylxanthine $(0.5 \mu \mathrm{M})$, insulin $(10 \mathrm{mg} / \mathrm{mL})$, and indomethacin $(100 \mu \mathrm{M})$ for 14 days. Differentiated into osteoblasts, the ADSCs were treated with low glucose DMEM FBS, supplemented with $10 \%$ dexamethasone $(0.1 \mu \mathrm{M})$, ascorbic acid $(0.2 \mu \mathrm{M})$, and beta glycerol phosphate $(10 \mathrm{mM})$ for 28 days. All the reagents were acquired from Sigma-Aldrich.

\section{Animal model of CKD}

Female C57BL/6J mice with 8 weeks of age coming from Centro de Desenvolvimento de Modelos Experimentais (CEDEME) of the Universidade Federal de São Paulo (UNIFESP) were submitted to unilateral renal ischemia, as described by Burne-Taney et al ${ }^{(26)}$. The animals were submitted to abdominal incisions, and their right renal pedicles were dissected. A microvascular clamp (Rocca, São Paulo, SP, Brazil) was placed on the left renal pedicle for 60 minutes, and the animals were maintained at an approximate temperature of $37^{\circ} \mathrm{C}$. The animals were monitored and maintained for 24 hours, and for 6 and 10 weeks before being euthanized. Sham animals were submitted to the same surgical procedure, but without renal artery clamping. All experimental procedures were approved by the Research Ethics Committee of UNIFESP (CEP process \# 1915/2008).

\section{Treatment with ADSCs}

Four hours after the surgical procedure, one group of animals received ADSCs intraperitoneally and was euthanized 24 hours and 6 weeks after surgery. Another group received ADSCs intraperitoneally 6 weeks after surgery, and was euthanized at the $10^{\text {th }}$ week. About $2 \times 10^{5}$ cells were administered to each animal.

\section{Evaluation of the renal function}

Serum creatinine was measured by the modified Jaffé method. Serum urea was measured using the Labtest kit (Labtest, Lagoa Santa, MG, Brazil).

\section{Morphology}

The kidneys of the animals euthanized at the $6^{\text {th }}$ and $10^{\text {th }}$ weeks after ischemia were analyzed with the use of Masson and Picrosirius stains. For histological tests, the kidneys were fixed in buffered $10 \%$ formaldehyde for 24 hours, washed with $70 \%$ ethanol for 24 hours, and then immersed in paraffin. The histological slices were $4 \mu \mathrm{m}$ thick. In order to assess the degree of expansion of the renal interstitium, the fraction of the renal cortex occupied by the interstitial tissue stained positively for components of the extracellular matrix (collagen) was evaluated quantitatively using Masson staining and a technique of counting consecutive points in microscopic fields, with a final magnification of $100 x$ on a 176point grid. Picrosirius staining was measured with 20x magnification using the NIS-Element Nikon, program of microscopy elements, with at least 20 consecutive fields. Acute tubular necrosis (ATN) was evaluated by a blind reviewer in slices of kidneys stained with hematoxylin and eosin.

\section{Real-time polymerase chain reaction}

Samples of renal tissue were rapidly frozen in liquid nitrogen. The total RNA was isolated using the Trizol reagent (Invitrogen, Carlsbad, CA, USA), and concentrations of RNA were determined by Nanodrop. First, cDNAs were synthesized from MML-V reverse transcriptase (Promega, Madison, USA). Reverse transcriptase and polymerase chain reaction (PCR) 
were performed using TaqMan (Applied Biosystem, USA) for molecules: Col-1 (00801666_g1), CTGF (Mm01192931_g1), IL-1ß (Mm01336189_m1), IL-4 (Mm00445259_m1), IL-6 (00561420_m1), IL-10 (Mm00439616_m1), iNOS (Mm01309902_m1), HO-1 (Mm00516004_m1), HPRT (Mm00446968_m1), Sry (Mm00441712_s1), TNF- $\alpha$ (Mm00443258 m1), VEGF (Mm01281449-m1), and Vimentin (00449201_m1). The cycles obeyed the following conditions: 10 minutes at $95^{\circ} \mathrm{C}$, followed by 45 cycles of 20 seconds each at $95^{\circ} \mathrm{C}$, 20 seconds at $58^{\circ} \mathrm{C}$, and 20 seconds at $72^{\circ} \mathrm{C}$. RT-PCR was carried out using SYBR Green real-time PCR (Applied Biosystem, USA) for HPRT (sense) 5-CTC ATG GAC TGA TTA ACA TGG GGA C-3 (antisense) 5-GCA GGT CAG CAA AGA TAT ACT AGC C-3; BMP-7 (sense) 5-ATT AGA CTT CCA CCC TCG ATA CC-3 (antisense) 5-TCC TTA TAG ATC CTG TCG AAT GCT-3 and TGF- $\beta$ (sense) 5-AAC TAT TTC TGC AGC TCC ACA GAG A-3 (antisense) 5-TGG AGT ATG GTA GCC TTG G-3. Sequence detection software 1.9 (SDS) was utilized for the analysis, and mRNA expression was normalized by HPRT. Values are expressed relative to a reference sample (calibrator): samples from the Sham animals. The $\mathrm{Ct}$ (limit cycle) for the target-gene and the $\mathrm{Ct}$ for the internal control were determined for each sample. Triplicate samples were used. The relative expression of mRNA was calculated by $2^{\Delta \Delta C T}$. All experimental samples were expressed as a difference $\mathrm{n}$ times the calibrator.

\section{Bioplex}

The assay kit Bioplex for use in mice with 23 plex of cytokines (Bio-Rad Laboratories, Inc., Hercules, CA, USA) was employed to test samples for the presence of 23 cytokines. The assay was read on the Bioplex matrix suspension system, and data were analyzed using BioPlex software Manager 4.0. Standard curves varied from 32.000 to $1.95 \mathrm{pg} / \mathrm{mL}$.

\section{Immunohistochemistry}

Collagen I (diluted at 1:200; COL-1, Abcam, Cambridge, MA, USA), FSP-1 (diluted at 1:400, S100A4, DAKO), PCNA (diluted at 1:300; clone PC10, DAKO), and Hypoxyprobe (diluted at 1:500; 121 Turnpike Middlesex, Burlington, MA, USA) were carried out on histological slices fixed in paraffin. The slides were previously deparaffinized, rehydrated, and submitted to a solution for Tris-EDTA antigen recovery, with $\mathrm{pH} 9$ and at $95^{\circ} \mathrm{C}$. For the Hypoxyprobe, antigen recovery was performed with $10 \mathrm{mM}$ citrate buffer, with $\mathrm{pH} 6$, at $55^{\circ} \mathrm{C}$. The activity of endogenous peroxidase was blocked by $3 \%$ hydrogen peroxide, besides the blockage with the Protein Block Solution (DAKO, Carpinteria, CA, USA). Next, the slides were incubated with a primary antibody or negative control reagent, followed by incubation with Envision (DAKO), using sequential 30-minute incubations at room temperature. Staining was completed by a 1 to 3 -minute incubation with 3.3-diaminobenzidine $(\mathrm{DAB})+$ chromogenic substrate, which resulted in a brown precipitate in the presence of antigen. Counter-staining with hematoxylin was performed. For the analysis of tissue hypoxia, intraperitoneal HypoxyprobeTM_1 (pimonidazole $\mathrm{HCl}$ ) was administered, at the dose of $60 \mathrm{mg} / \mathrm{kg}$ of body weight, approximately 25 minutes before euthanization. After inoculation, HypoxyprobeTM_1 (121 Turnpike Middlesex, Burlington, MA, USA) was distributed throughout all tissues, but it adhered only to certain proteins from cells that had an oxygen concentration lower than 14 micromolar - the equivalent of a partial pressure $\mathrm{pO} 2=10 \mathrm{mmHg}$ at $37^{\circ} \mathrm{C}$.

\section{Statistical analysis}

Data were expressed with mean \pm SD. The differences between the two groups were assessed as to statistical significance with Student's $t$-test and ANOVA. Differences were considered significant for $\mathrm{p}<0.05$.

\section{RESULTS}

\section{ADSC isolation and characterization}

ADSCs were characterized by immunophenotypical assays using a few cell surface markers described in literature $^{(20)}$. CD34, CD73, CD105, and CD45 were evaluated. The expression of CD73 was $24.9 \pm 0.9 \%$; CD105: $71.2 \% \pm 19.7$; CD34: $6.0 \pm 3.8 \%$; and CD45: $6.9 \% \pm 1.9$. These results were expected in regard to the immunophenotypical profile described for ADSCs. First passage cells were characterized by differentiation into adipocytes in parallel assays. In cells differentiated into adipocytes, it was possible to visualize red drops of lipids inside the cells stained with Oil Red. The differentiation into osteocytes was performed, and after 28 days, calcium deposits were observed using Von Kossa staining (data not shown).

\section{Treatment with ADSCs leads to tissue and systemic immunomodulation}

In this model, serious ischemia and reperfusion occurred in only one kidney. However, due to the prolonged time of ischemia (1 hour), renal functional parameters were altered. Serum levels of urea were increased in animals subjected to severe ischemia when compared to Sham 
animals. Treatment with ADSCs displayed inferior renal dysfunction (Figure 1A). These results correlated with ATN. Kidneys submitted to ischemia after 24 hours showed a larger area of necrosis (Figure 1B), while ATN was decreased in animals treated with ADSCs. Additionally, the pattern of regeneration was superior in animals treated with ADSCs (Figures $1 \mathrm{C}$ and $1 \mathrm{E}$ ) confirmed by PCNA marking (Figures $1 \mathrm{~F}$ to $1 \mathrm{H}$ ).

Inflammation plays a significant role in the results of renal ischemia and reperfusion. In addition, it is known that ADSCs lead to immunomodulation. In this sense, we analyzed the expression of mRNA of various cytokines after treatment with ADSCs. The expression of IL- 6 mRNA was reduced in the renal tissue of animals treated with ADSCs (Figure 1I). The expression of TNF- $\alpha$ and IL- $1 \beta$ mRNA was also quantified, but no statistical differences were noted (Figures $1 \mathrm{~J}$ and $1 \mathrm{~K})$, although the animals treated with ADSCs showed greater expression. Surprisingly, the expression of the mRNA of anti-inflammatory cytokines IL-4 and IL-10 was increased in the renal tissue of animals treated with ADSCs (Figures $1 \mathrm{~L}$ and $1 \mathrm{M}$ ).

Systemically, we identified the same immunomodulation pattern found in renal tissue. Serum proinflammatory cytokines, such as IL-1 $\alpha$, IL$1 \beta, \mathrm{KC}$, and IL-12 (p70), were reduced in the group of animals treated with ADSCs (Figures 1N, 1P, 1R, 1T). The levels of IL- 6 and IL-13 were also evaluated, but no significant differences were observed (Figures 10 and 1S). RANTES levels were also reduced in animals treated with ADSCs (Figure 1T). In this multiplex assay, G-CSF, GM-CSF, IL-12 (p40), MCP-1, MIP-1 $\beta$, and levels of TNF- $\alpha$ in animals treated with ADSCS did not differ from untreated animals. Additionally, IL-12, IL-3, IL-4, IL-10, IL-17, MIP-1a and IFNg were not detected in this assay.

In order to verify the presence of ADSCs within the kidneys after treatment, the expression of SRY mRNA was amplified by PCR in real-time (Figure 1U). No intensities of SRY mRNA were detected, indicating the absence of these cells within the tissue at this time of the study.

\section{ADSC ceases the progression of fibrosis resulting from severe ischemia}

After 6 weeks, in this model of reperfusion ischemia, it was noted that the kidney submitted to ischemia was smaller in comparison to the contralateral kidney in non-treated animals. Surprisingly, the ischemic kidney of the animals treated with ADSCs was not reduced in size (Figure 2A). Even so, the levels of creatinine and urea did not change under treatment with ADSCs, possibly due to the presence of the contralateral kidney, which gradually compensates the functional loss of the damaged kidney (Figures $2 \mathrm{~B}$ and 2C). This reducedsize kidney also showed a larger area of fibrosis, as demonstrated with Masson trichrome and Picrosirius staining (Figures 2D to $2 \mathrm{~F}$ ). No relevant fibrosis was observed in the sham group.

We also quantified the expression of mRNA of a few profibrotic molecules in order to ratify our data as to collagen deposition. Type 1 collagen (Col-1), vimentin, and connective tissue growth factor (CTGF) were evaluated in renal tissue after 6 weeks. Once again, a reduced expression of the mRNA of these molecules was noted in the renal tissue of the animals treated with ADSCs (Figures 3A to 3C). In addition, in order to confirm these results, protein analyses were performed by means of immunohistochemistry for FSP-1 (fibroblastspecific protein 1) and Col-1 (Figure 4).

\section{Immunomodulation of inflammation by ADSCs}

As early as 24 hours after serious ischemia and reperfusion, a significant modulation of the inflammatory response was noted in animals treated with ADSCs. Since this reduced inflammation at the initial time point could be related to the progression of fibrosis, we investigated the inflammatory pattern inside the kidney and, systemically, 6 weeks after the treatment. Additionally, we quantified a few protective and angiogenic molecules related to tissue repair. In 6 weeks, the expressions in the kidney of proinflammatory cytokines, such as TNF- $\alpha$ and IL-6, were still reduced in the animals submitted to severe ischemia and treated with ADSCs (Figures 3D and 3E). Also, heme oxygenase 1 (HO-1) and the BMP-7/TGFb ratio were increased in the animals treated with ADSCs compared to those not treated (Figures 3F and 3G). Therapy with ADSCs also led to systemic immunomodulation. Serum levels of cytokines were reduced in animals treated with ADSCs. The levels of IL- $1 \alpha$, TNF- $\alpha, \mathrm{KC}$, and RANTES were significantly reduced in treated animals when compared to those not treated (Figures $3 \mathrm{~K}, 3 \mathrm{M}, 3 \mathrm{~N}$, and $3 \mathrm{O}$ ). IL-6 and other cytokines (IL-1 $\beta$, IL-10, and IL-17) did not differ between the groups, although a tendency of reduction in animals treated with ADSCs was observed (Figure 3L and supplementary data).

Chronic hypoxia, due to rarefied capillaries, is a possible theory to explain the continued progression of renal fibrosis, since low oxygen pressure is an important factor for EMT. Therefore, we analyzed whether tissue hypoxia was reduced in renal tissue by using a probe that detects areas of low pO2. The ischemic kidneys of animals treated with ADSCs demonstrated areas of lower hypoxia (Figure 3J). Additionally, the expression of iNOS mRNA was increased in the kidneys of animals 
A B

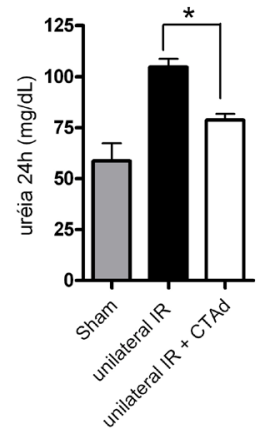

F
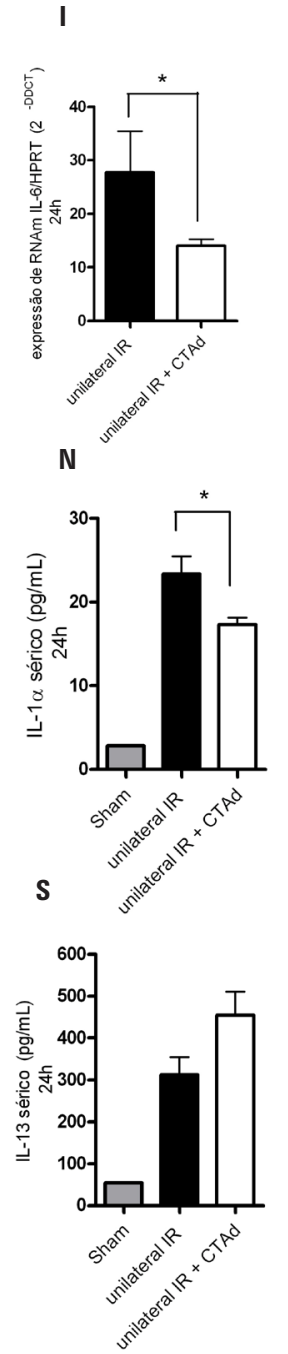
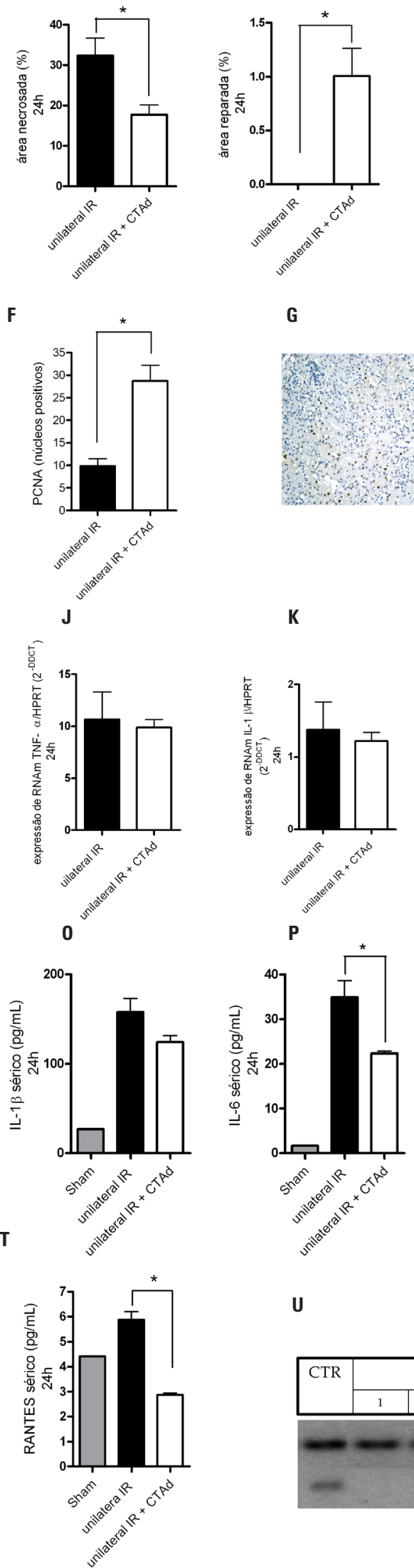

G

K

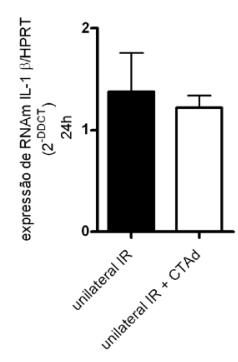

$\mathbf{U}$
C

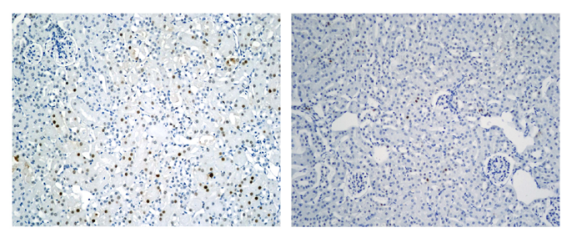

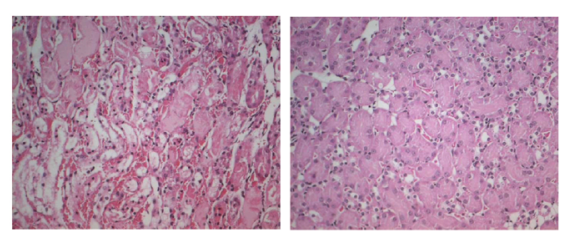

H
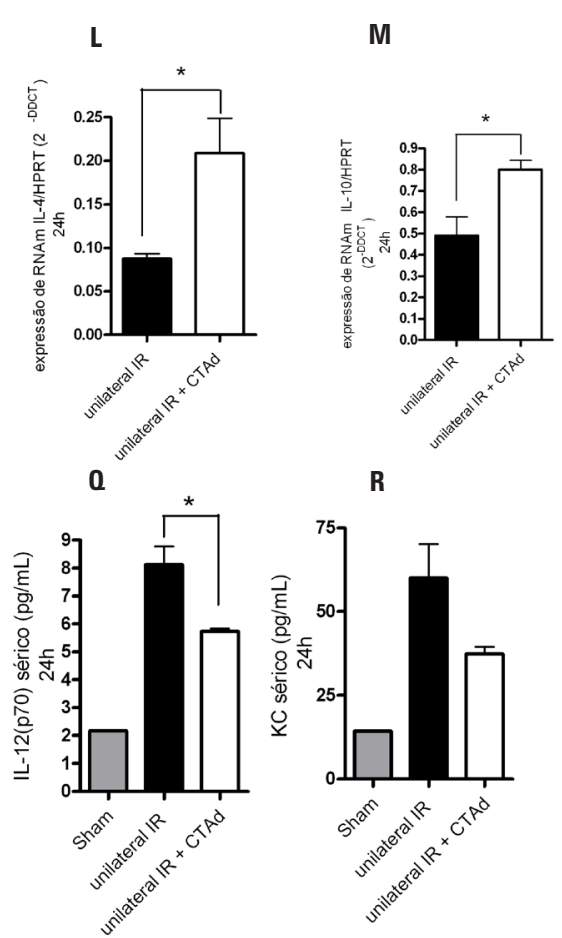

Figure 1. Effects of administration of adipose tissue-derived stem cells after 24 hours of unilateral ischemia. 
A

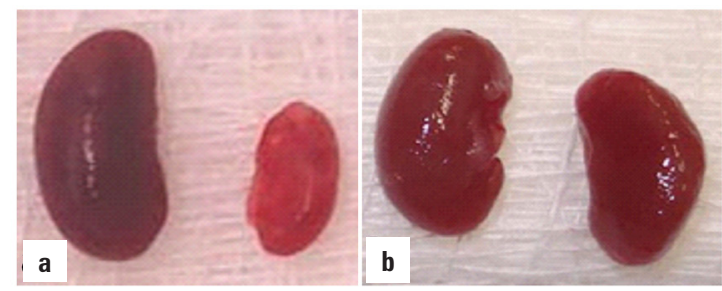

B

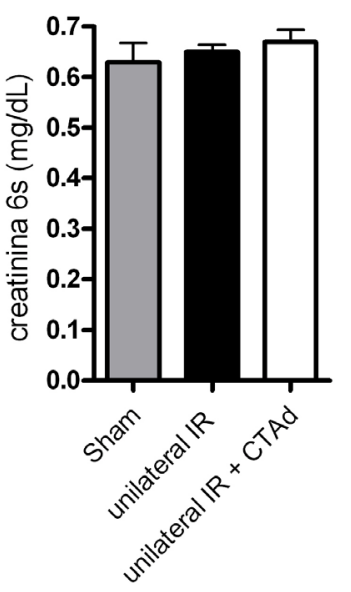

D Sham $\quad$ IR $6 \mathrm{~s}$

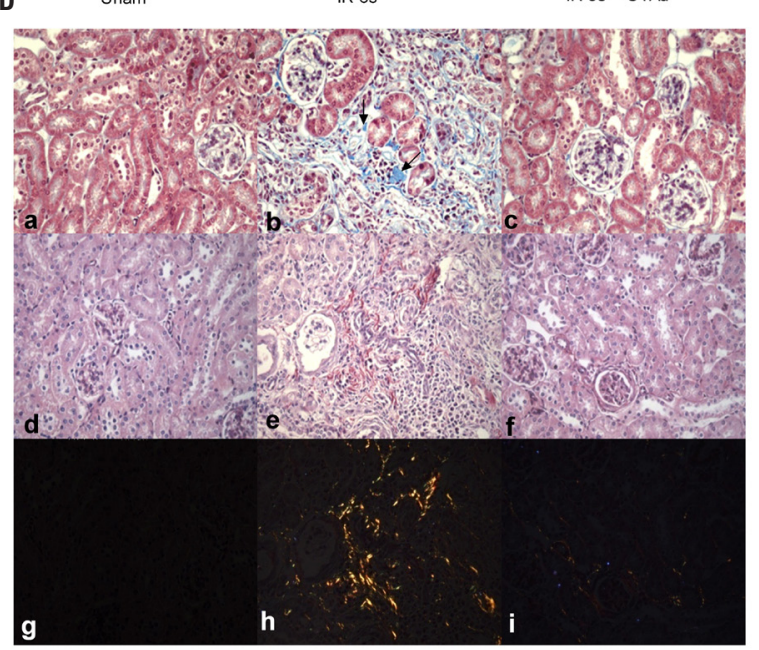

E

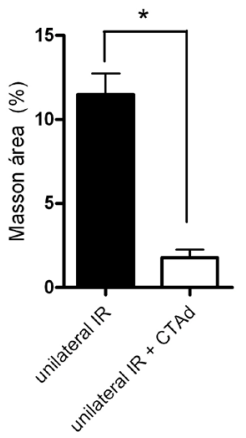

C

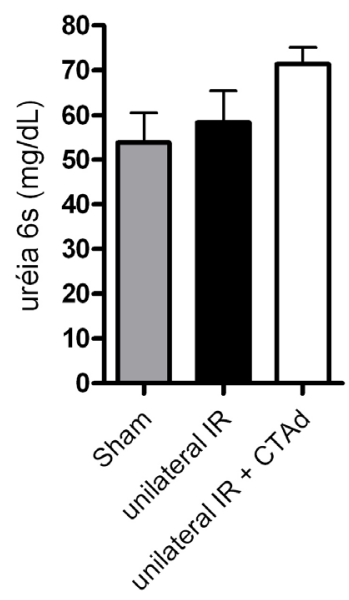

IR 6s + CTAd

F

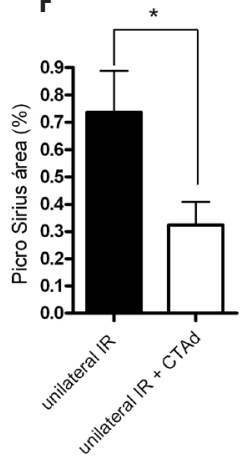

Figure 2. Effects of administration of adipose tissue-derived stem cells in mice after 6 weeks of unilateral ischemia.

treated with ADSCs, despite significant differences not having been found in the expression of VEGF (Figures $3 \mathrm{H}$ and $3 \mathrm{I})$.

\section{Reversal of renal fibrosis after treatment with ADSCs}

We tested the role of ADSCs in reversing an established fibrotic condition. ADSCs were administered 6 weeks after ischemia, and the animals were observed until the $10^{\text {th }}$ week. Amazingly, the kidneys of animals treated with ADSCs showed reduced areas of fibrosis, as per analysis with Picrosirius staining (Figures 5C and 5D). A functional improvement was also noted and correlated with the reduction of these areas of fibrosis (Figures 5A and 5B). Confirming these data, the expression of vimentin mRNA was reduced in animals treated with ADSCs when compared to those not treated (Figure 6). The expression of Col-1 mRNA was also diminished in animals treated with ADSCs, but no significant difference was observed (Figure 6B). In addition, the immunohistochemical test for Col-1 and FSP-1 correlates with the studies of the genes analyzed (Figure 6E). The mRNA expression of protective cytokines such as IL-10 and BMP-7 increased after treatment with ADSCs (Figures 6C and 6D). Once again, despite this functional and histological improvement, ADSCs were not found in the kidney, according to analysis of the expression of SRY mRNA (Figure 6F).

\section{DISCUSSION}

ADSCs were first described by Zuk et al. ${ }^{(27)}$ in 2002. Since then, studies with ADSCs have been growing exponentially. The regenerative properties of ADSCs are greatly attractive for many diseases ${ }^{(28)}$. Fibroproliferative diseases call our attention because the tissue destruction caused by deposition of extracellular matrix leads to functional loss of the organ. This is very important for the kidneys since the balance between cells and extracellular matrix determines their function.

CRD is emerging as a worldwide health problem. The plausible therapies for the final stage of renal failure today are dialysis and transplantation. Nevertheless, these treatments do not solve this problem ${ }^{(29)}$. Various comorbidities may cause CRD, but one aspect is always forgotten: persistent inflammation after ARF events ${ }^{(30,}$ ${ }^{31)}$. Inflammation is the primary factor in the progression of renal fibrosis. It leads to the transformation of epithelial cells into myofibroblasts, known as EMT ${ }^{(4)}$. There is no consensus as to whether EMT occurs in vivo. However, the role of inflammation in scar formation is not questionable. 
A

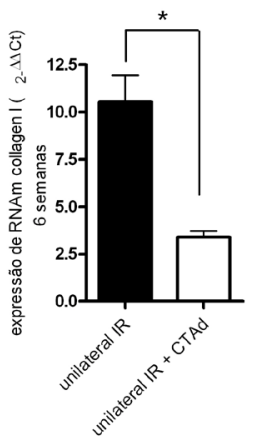

$\mathbf{F}$

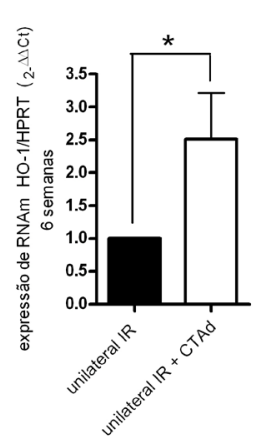

B

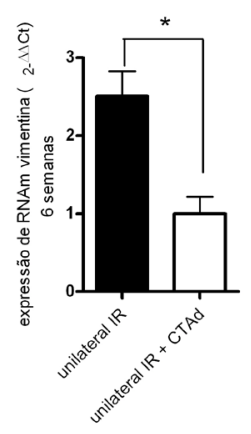

G
C

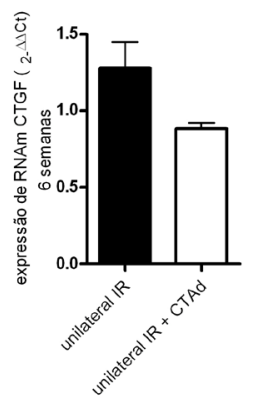

D

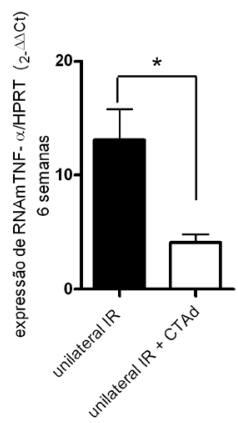

H

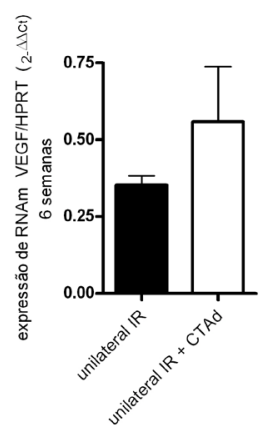

E
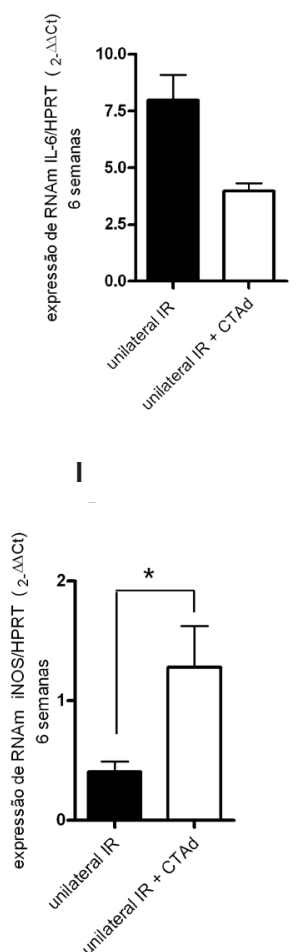

J

Sham

IR 6s

IR $6 s+C T A d$

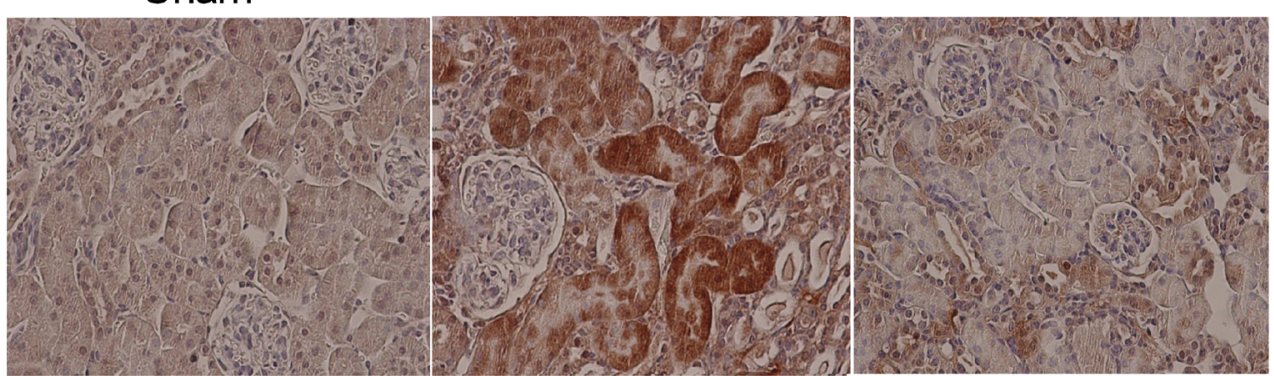

K

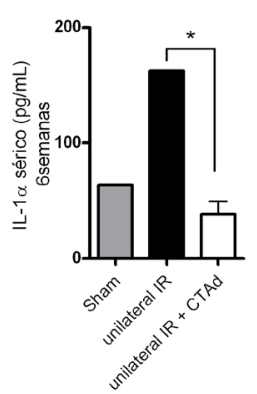

L

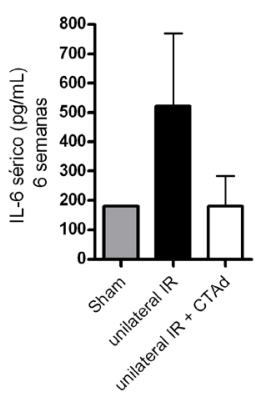

M

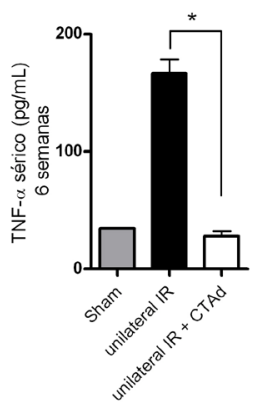

N

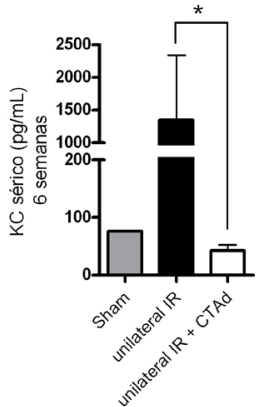

0

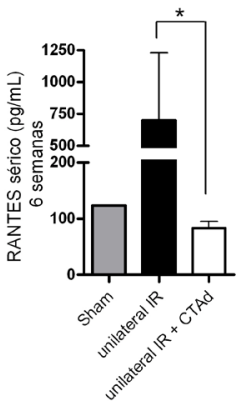

Figure 3. Expression of cytokines in serum and renal tissue of animals sacrified 6 weeks after reperfusion. 


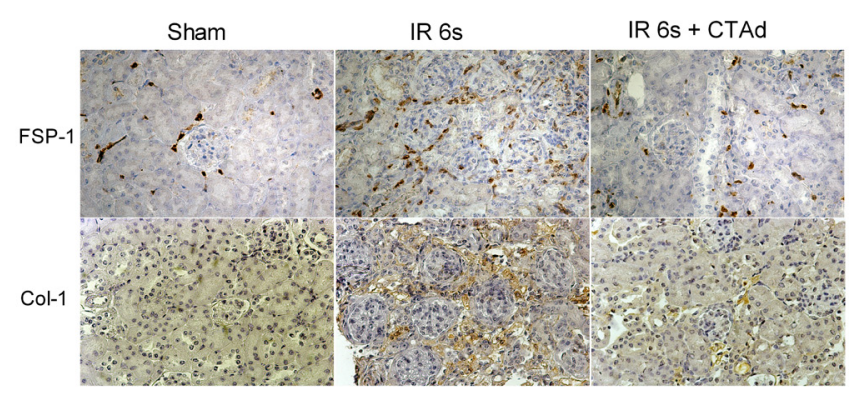

Figure 4. Immunohistochemistry of renal tissue after 6 weeks.
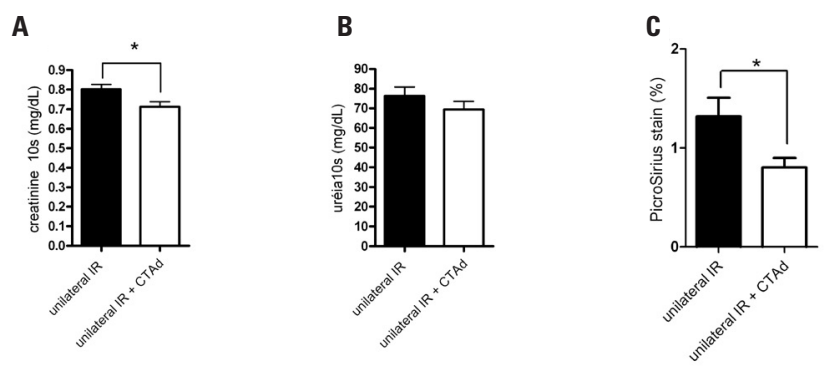

D

IR 10s

IR 10 s + CTAd

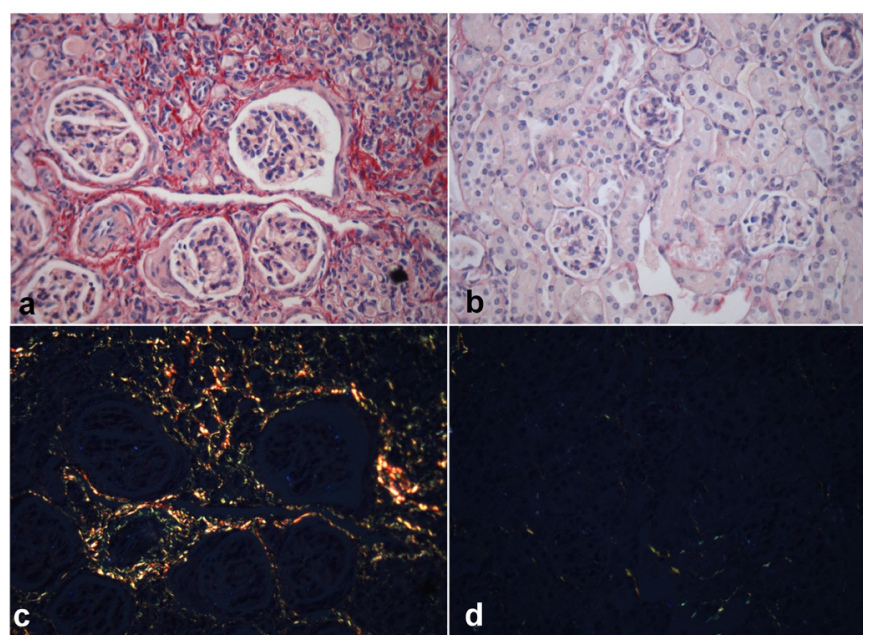

Figure 5. Effects of administration of adipose tissue-derived stem cells in week 6 after ARF, analyzed after 10 weeks.

Despite the functional improvement after acute kidney damage, a residual inflammation may contribute to epithelial stress that leads to fibrosis. In this model of serious unilateral ischemia, residual inflammation leads the kidney to decrease in size due to the cicatricial fibrosis formed.

The primary mechanism of action of adult stem cells is immunoregulation ${ }^{(23,24)}$. This occurs by means of a predominantly paracrine effect of the ADSCs, via a "touch and go" phenomenon in which these cells are attracted to the site of the lesion, secrete immune factors, and then leave that tissue or die. This may
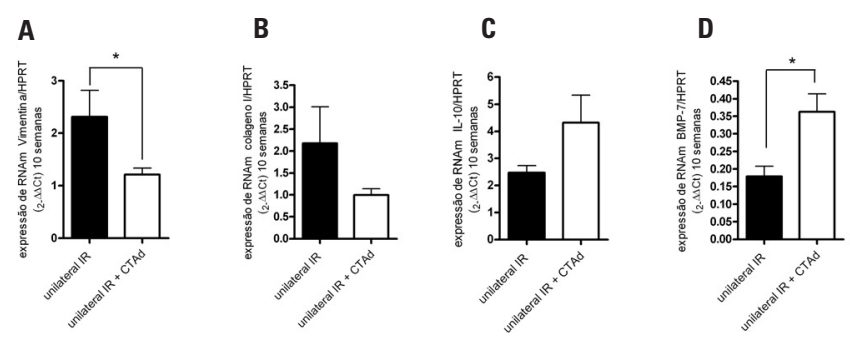

E

SHAM

IR 10s

IR 10s + CTAd

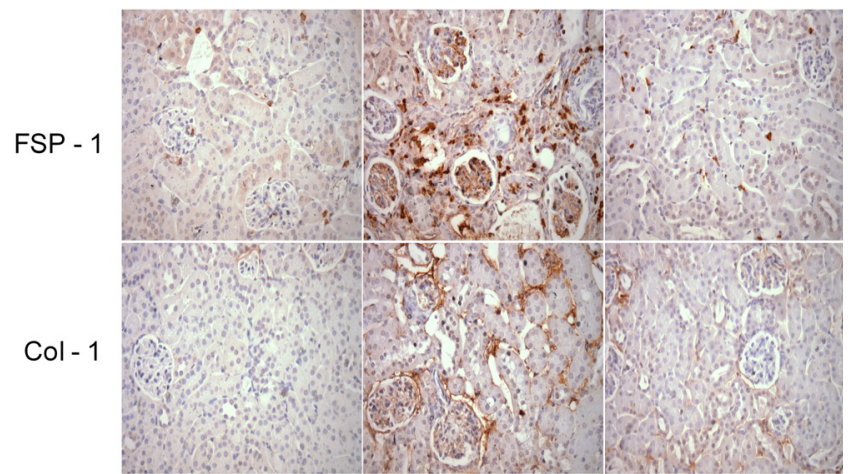

F

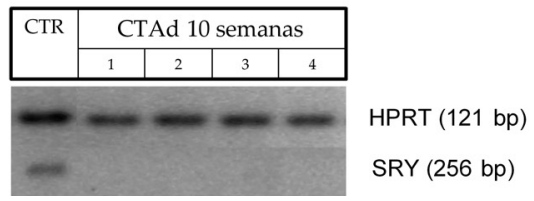

Figure 6. Expression of cytokines in renal tissue of animals 10 weeks after reperfusion.

explain why ADSCs were not seen in the kidneys of treated animals.

In this project, we proposed that ADSCs may inhibit EMT by acting on inflammation. In 24 hours, the animals treated with ADSCs had better functional results correlated with immunomodulation, which is reflected after 6 weeks when smaller areas of fibrosis are observed.

In our results, over 10 weeks of analyses we were able to observe that, besides the fibrotic process, ADSCs were capable of reversing this condition of fibrosis. This opens an incredible opportunity for clinical treatment. We focus, then, on inflammatory results. Once again, the animals treated with ADSCs had low levels of inflammation, which might be reflected in the reduced progression of extracellular matrix deposition.

In summary, we propose that treatment with ADSCs may lead to a halt in the progression or even to the reversal of the fibrotic process by downregulation of the inflammation, via systemic administration. 


\section{REFERENCES}

1. Mehta RL, Pascual MT, Soroko S, Savage BR, Himmelfarb J, Ikizler TA, et al. Spectrum of acute renal failure in the intensive care unit: the PICARD experience. Kidney Int. 2004;66(4):1613-21.

2. Levy EM, Viscoli CM, Horwitz RI. The effect of acute renal failure on mortality. A cohort analysis. JAMA. 1996;275(19):1489-94.

3. Kalluri R. EMT: when epithelial cells decide to become mesenchymal-like cells. J Clin Invest. 2009;119(6):1417-9.

4. Kalluri R, Weinberg RA. The basics of epithelial-mesenchymal transition. J Clin Invest 2009;119(6):1420-8.

5. Okada H, Inoue T, Suzuki H, Strutz F, Neilson EG. Epithelial-mesenchymal transformation of renal tubular epithelial cells in vitro and in vivo. Nephrol Dial Transplant. 2000;15 Suppl 6:44-6.

6. Strutz F, Neilson EG. New insights into mechanisms of fibrosis in immune renal injury. Springer Semin Immunopathol. 2003;24(4):459-76.

7. Liu X. Inflammatory cytokines augments TGF-beta1-induced epithelialmesenchymal transition in A549 cells by up-regulating TbetaR-I. Cell Motil Cytoskeleton. 2008;65(12):935-44.

8. Leask A, Abraham DJ. TGF-beta signaling and the fibrotic response. Faseb J. 2004;18(7):816-27.

9. Zeisberg M, Yang C, Martino M, Duncan MB, Rieder F, Tanjore $H$, et al. Fibroblasts derive from hepatocytes in liver fibrosis via epithelial to mesenchymal transition. J Biol Chem. 2007;282(32):23337-47.

10. Bachelder RE, Yoon SO, Franci $C$, de Herreros AG, Mercurio AM. Glycogen synthase kinase-3 is an endogenous inhibitor of Snail transcription: implications for the epithelial-mesenchymal transition. J Cell Biol. 2005;168(1):29-33.

11. Wu Y, Deng J, Rychahou PG, Qiu S, Evers BM, Zhou BP. Stabilization of snail by NF-kappaB is required for inflammation-induced cell migration and invasion. Cancer Cell. 2009;15(5):416-28.

12. Guijarro C, Egido J. Transcription factor-kappa B (NF-kappa B) and renal disease. Kidney Int. 2001;59(2):415-24.

13. Segerer S, Nelson PJ, Schlöndorff D. Chemokines, chemokine receptors, and renal disease: from basic science to pathophysiologic and therapeutic studies. J Am Soc Nephrol. 2000;11(1):152-76.

14. Lange-Sperandio B, Trautmann A, Eickelberg 0, Jayachandran A, Oberle S, Schmidutz $F$, et al. Leukocytes induce epithelial to mesenchymal transition after unilateral ureteral obstruction in neonatal mice. Am J Pathol. 2007;171(3):861-71.

15. Zuk PA, Zhu M, Mizuno H, Huang J, Futrell JW, Katz A, et al. Multilineage cells from human adipose tissue: implications for cell-based therapies. Tissue Eng. 2001;7(2):211-28.

16. Bi B, Schmitt R, Israilova M, Nishio H, Cantley LG. Stromal cells protect against acute tubular injury via an endocrine effect. J Am Soc Nephrol. 2007;18(9):2486-96 .
17. Gimble JM, Katz AJ, Bunnell BA. Adipose-derived stem cells for regenerative medicine. Circ Res. 2007;100(9):1249-60.

18. Yañez R, Lamana ML, García-Castro J, Colmenero I, Ramírez M, Bueren $\mathrm{JA}$, et al. Adipose tissue-derived mesenchymal stem cells have in vivo immunosuppressive properties applicable for the control of the graft-versushost disease. Stem Cells. 2006;24(11):2582-91.

19. Fang B, Song Y, Zhao RC, Han Q, Lin Q. Using human adipose tissue-derived mesenchymal stem cells as salvage therapy for hepatic graft-versus-host disease resembling acute hepatitis. Transplant Proc. 2007;39(5):1710- 3.

20. Rasmusson I, Ringdén 0, Sundberg B, Le Blanc K. Mesenchymal stem cells inhibit lymphocyte proliferation by mitogens and alloantigens by different mechanisms. Exp Cell Res. 2005;305(1):33-41.

21. Aggarwal S, Pittenger MF. Human mesenchymal stem cells modulate allogeneic immune cell responses. Blood. 2005;105(4):1815-22.

22. Ivanova-Todorova E, Bochev I, Mourdjeva M, Dimitrov R, Bukarev D, Kyurkchiev $S$, et al. Adipose tissue-derived mesenchymal stem cells are more potent suppressors of dendritic cells differentiation compared to bone marrow-derived mesenchymal stem cells. Immunol Lett. 2009;126(1-2): 37-42.

23. Semedo P, Correa-Costa M, Antonio Cenedeze M, Maria Avancini Costa Malheiros D, Antonia dos Reis M, Shimizu MH, et al. Mesenchymal stem cells attenuate renal fibrosis through immune modulation and remodeling properties in a rat remnant kidney model. Stem Cells. 2009; 27(12): 3063-73.

24. Semedo P, Palasio CG, Oliveira CD, Feitoza CO, Gonçalves GM, Cenedeze $M A$, et al. Early modulation of inflammation by mesenchymal stem cell after acute kidney injury. Int Immunopharmacol. 2009;9(6):677-82.

25. Moon MH, Kim SY, Kim YJ, Kim SJ, Lee JB, Bae YC, et al. Human adipose tissue-derived mesenchymal stem cells improve postnatal neovascularization in a mouse model of hindlimb ischemia. Cell Physiol Biochem. 2006;17 (5-6):279-90.

26. Burne-Taney MJ, Yokota N, Rabb H. Persistent renal and extrarenal immune changes after severe ischemic injury. Kidney Int. 2005; 67(3):1002-19.

27. Zuk PA, Zhu M, Ashjian P, De Ugarte DA, Huang Jl, Mizuno H, et al. Human adipose tissue is a source of multipotent stem cells. Mol Biol Cell. 2002; 13(12):4279- 95.

28. Zuk PA. The Adipose-derived stem cell: looking back and looking ahead. Mol Biol Cell. 2010;21(11):1783-7

29. Levey AS, Stevens LA, Coresh J. Conceptual model of CKD: applications and implications. Am J Kidney Dis. 2009;53(Suppl 3):S4-16.

30. Rodríguez-Iturbe B, García GG. The role of tubulointerstitial inflammation in the progression of chronic renal failure. Nephron Clin Pract. 2010;116(2):c81-8

31. Wynn TA. Cellular and molecular mechanisms of fibrosis. J Pathol. 2008;214(2):199-210. 